\title{
DREDGING OPTIMIZATION OF AN INLET SYSTEM FOR ADJACENT SHORE PROTECTION PROJECTS USING CMS AND GENCADE
}

\author{
Tanya M. Beck ${ }^{1}$ and Kelly R. Legault, Ph.D. ${ }^{2}$
}

\begin{abstract}
St. Johns County encompasses a 24-km beach and inlet system located in northeast Florida (United States) that includes several interconnected Federal Navigation and Shore Protection Projects that must be managed within a regional context to reduce cost, share sediment, and optimize the volume of sand within the littoral system. The objective of this study is to investigate optimal dredging volumes and intervals, and to determine the beach placement volume and renourishment interval to maintain two Shore Protection Projects. The Coastal Modeling System (CMS) was applied to analyze the morphological impact on the sediment dynamics for ebb-tidal delta mining at $\mathrm{St}$. Augustine Inlet over 1.4-year simulations. Results determined that dredging scenarios under 4 Mill cu yd removed did not significantly modify the ebb-tidal delta. The CMS modeling results on sustainable dredging volumes, combined with historical infilling rates, provided constraints with which to develop dredging and beach fill scenarios for GenCade, a 1-D numerical model that predicts shoreline change. GenCade was applied to evaluate sediment management alternatives for dredging intervals of 5, 7 and 10 years, and varying beach fill volumes and placement lengths. Results indicate that imposing a 10-year dredging interval to the navigation project and ebb delta with the maximum dredging quantity of 3 million cubic yards will yield the best performance of the regional projects of St. Johns County. GenCade calculates future sediment budgets for various management scenarios, and can provide an essential benefit in determining optimal dredging periods for coordinated regional efforts to save in mobilization and demobilization costs for dredging and beach fill placement.
\end{abstract}

Keywords: dredging optimization, ebb-tidal delta mining, tidal inlets, regional sediment managmenet, coastal modeling, sediment budgets

\section{INTRODUCTION}

St. Johns County encompasses a 24-km beach and inlet system located in northeast Florida on the Atlantic coastline of the U.S (Figure 1). St. Johns County includes several interconnected Federal navigation and shore protection projects that must be managed within a regional context to reduce cost, share sediment, and optimize the volume of sand within the littoral system. A comprehensive analysis of spatial and temporal data for St. Johns County, FL, was performed by the U.S. Army Engineer District, Jacksonville (hereafter, the Jacksonville District), and the Coastal Inlets Research Program (CIRP) at the Coastal and Hydraulics Laboratory (CHL), and are documented in three technical reports (Legault et al. 2012; Beck and Legault 2012a; Beck and Legault 2012b). These data were formulated into a present-day sediment budget in order to clearly define regional sediment dynamics for the purpose of subsequent regional sediment modeling and long-term planning of the sediment resources and shore protection needs for the county.

Numerical modeling has been conducted to adaptively manage and optimize Operations \& Maintenance practices, including navigation channel dredging and nearshore and beach placement of dredged sediment. The Coastal Modeling System (CMS; Demirbilek and Rosati 2011) is a numerical model that was applied to predict nearshore morphology change at medium-term timescales for the St. Augustine Inlet Navigation Project. Results of calculations in the CMS for dredging frequencies and volume change at St. Augustine Inlet were transferred to the Inlet Reservoir Model (Kraus 2000) within GenCade (Frey et al. 2012; Hanson et al 2011;), and applied via modification of sediment bypassing around the inlet. GenCade is a 1-D numerical model that predicts shoreline change over kilometers of coast, and can calculate regional sediment transport over long-term (decadal) horizons. The Inlet Reservoir Model is an aggregate model that calculates the volume change of separate morphologic aggregates within the inlet system that adhere to an equilibrium principle, and relies on the littoral sediment bypassing from adjacent beaches as the only source of sediment. These models were applied in an innovative manner to the St. Johns County domain to understand the regional sediment transport fluxes in the vicinity of St. Augustine Inlet and to optimize the planning of cooperative navigation and shore protection projects (SPP) (Figure 1).

\footnotetext{
${ }^{1}$ Research Physical Scientist. U.S. Army Corps of Engineers, Coastal and Hydraulics Laboratory, Engineer Research and Development Center. 3909 Halls Ferry Rd. Vicksburg, MS 39180, USA

${ }^{2}$ Senior Coastal Engineer. U.S. Army Corps of Engineers, Jacksonville District, 701 San Marco Blvd. Jacksonville, FL 32205 , USA.
} 


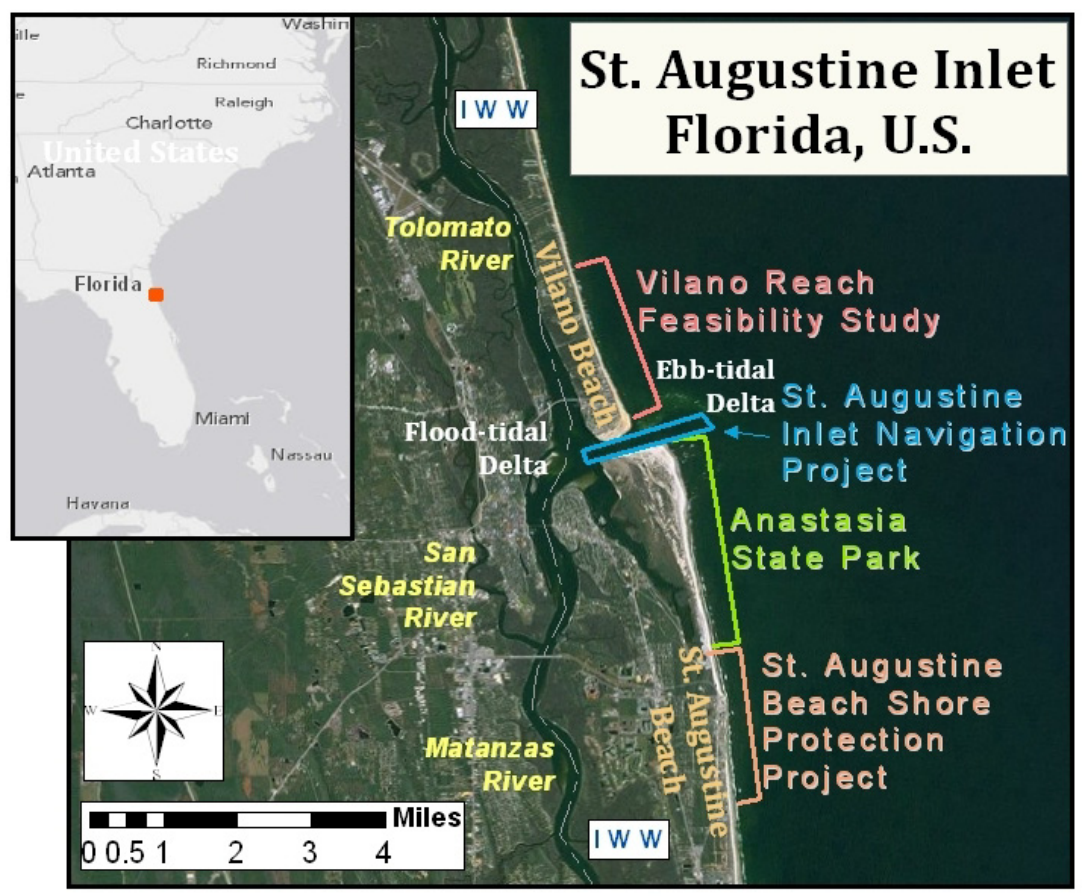

Figure 1. Study area location map for St. Johns County, Florida, and the U.S. Army Corps of Engineers' projects.: Vilano Reach Feasibility Study, St. Augustine Beach Nourishment Project, Intracoastal Waterway (IWW), and St. Augustine Inlet Navigation Project. The Vilano Shoal is located at the southern terminus of the Vilano Reach Feasibility Study, and the ebb-tidal delta mining is located adjacent and offshore of the Inlet Navigation Project.

\section{Study Area}

The wave climate of northeastern Florida is characterized as seasonal with moderate wave exposure as defined by Walton and Adams (1976); and, the tidal range is on the lower end of mesotidal with a spring high tidal range of $6 \mathrm{ft}$ and a mean of $5 \mathrm{ft}$ (NOAA, 2010a). Wave energy is typically greatest during the winter season from November to April, with subtropical frontal passages occurring on average every 3 to 7 days (Taylor Engineering Inc. 1996). Waves during these storms are typically out of the north with heights on average of 4 to $6 \mathrm{ft}$ or greater and mean wave periods of 9 to 12 seconds (USACE 2010). Figure 2 depicts the percent occurrence for wave height and period for the 20-year WIS hindcast period of 1980-1999. Fair-weather conditions persist through the summer season from May to October, with the exception of the occasional passage of tropical storms. Southerly waves during this season on average dominate and induce a reversal in net sediment transport direction. Overall, the net sediment transport along northeastern Florida is north to south, primarily caused by winter storms, although local reversal do occur.
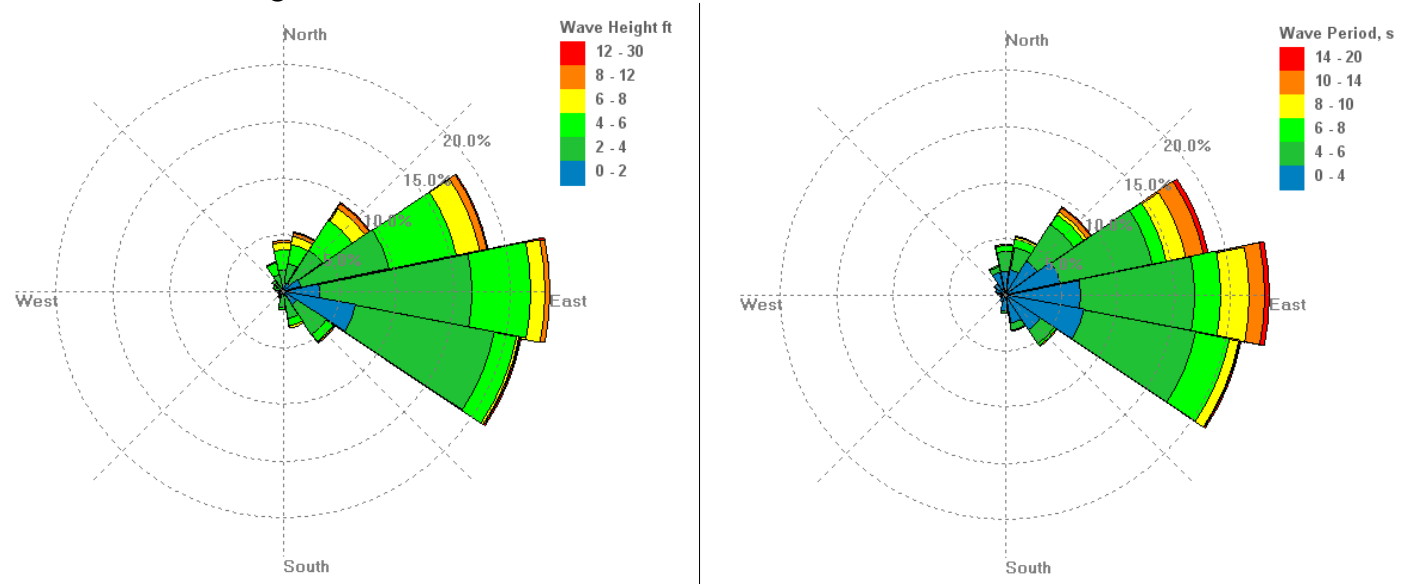

Figure 2. Wave height (left panel) and wave period (right panel) rose diagrams that give the percent occurrence of waves for the 20-year WIS hindcast for station 417. 
Sediments within the nearshore along northern St. Johns County are mostly littorally-derived quartz sand with varying fractions of carbonate shell hash. The grain-size distribution of the sediments is greatly varied in the alongshore. The net direction of regional sand transport and general trends of volumetric change observed from beach profiles (Figure 3), are described extensively by Legault et al. (2012). To summarize, Figure 3 (right) shows average annual volume change per summed profile reach (5000 ft) for the time period from 1986-1999 (pre-dredging) and for the time period from 19992007 (post-dredging). In general, for the pre-project period (1986-1999), there is erosion north of the inlet from R1-R122, with accretion immediately south of the inlet from R124-R128, which is the drumstick headland, and the point of greatest bypassing reach for St. Augustine Inlet. The greatest erosion occurs around R135 -R150, the headland and relic location of St. Augustine Inlet. Milder erosion occurs south of R150 until the southern terminus of the island at the next inlet. Beach nourishment projects are typically placed between R132-R151 as part of the Shore Protection Project at St. Augustine Beach.
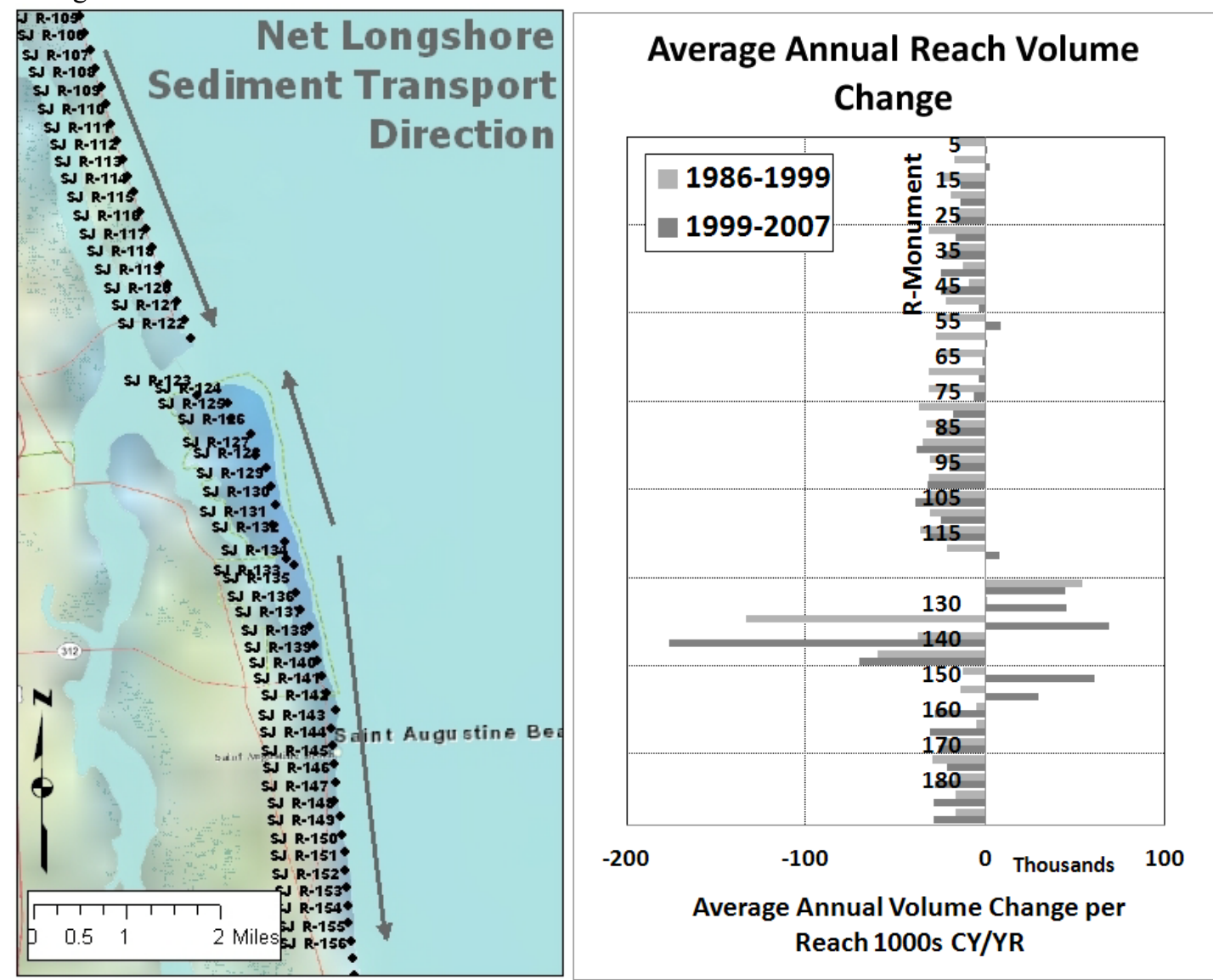

Figure 3. General net longshore sediment transport directions in the vicinity of the inlet, and average annual reach volume change 1986-1999 and 1999-2007. Reaches are approximately $5000 \mathrm{ft}$ in the alongshore.

\section{Historical Regional Sediment Management}

Since 1970, historical management practices at St. Augustine Inlet aimed toward maintaining the federal navigation channel and adjacent beaches involved dredging the navigation channel and placing that material onto the adjacent beaches in moderate quantities $(\sim 200-500 \mathrm{~K}$ cu yd) (personal communication with Jacksonville District). Since the inlet's design and relocation in 1940, the ebbtidal delta has been approaching an equilibrium size and morphology (Figure 4; Legault et al. 2012). Realizing this sediment reservoir as a suitable beach nourishment source, the Jacksonville District performed major dredging and adjacent beach fill operations in the early to mid-2000s. Approximately 4.2 Mill cu yd (million cubic yards) and 2.8 Mill cu yd of sand was placed from 2001 to 2005 along a Federally-maintained Shore Protection Project at St. Augustine Beach (Legault et al. 2012). Table 1 lists ebb-tidal delta volumes and Table 2 lists the volume of sediment removed from the inlet channel and its ebb-tidal delta from 1986 to 2010 . Nearly 7 Mill cu yd of sediment was removed from the inlet 
system between 1999 and 2007, and a slow rate of ebb-tidal delta recovery is evident in the volumetric change data in Table 1.

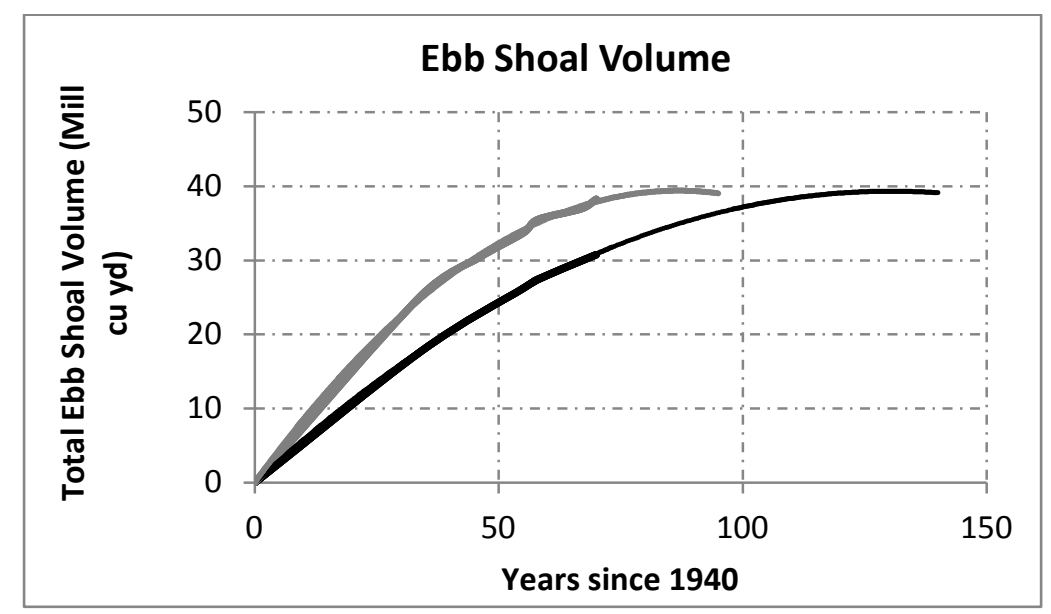

Figure 4. Reported Ebb-tidal Shoal Volumes (Taylor Engineering Inc. 1994; Beck and Legault 2012b) in the solid lines and extrapolated volumes in the dashed lines. Both the 26 - $\mathrm{ft}$ and $30-\mathrm{ft}$ contours were chosen as closure depths and so both were calculated. Approximately $\mathbf{4 0}$ Mill cu yd is the expected maximum volume.

\begin{tabular}{|c|c|}
\hline \multicolumn{2}{|c|}{$\begin{array}{l}\text { Table 1. Measured Ebb-delta Volume } \\
\text { of St. Augustine Inlet, Florida at the } \\
\text { 30ft contour (Legault et al. 2012). }\end{array}$} \\
\hline Date & Volume (mill cu yd) \\
\hline 1986 & 30.4 \\
\hline 1998 & 35.5 \\
\hline 1999 & 35.9 \\
\hline 2007 & 29.5 \\
\hline 2010 & 30.9 \\
\hline
\end{tabular}

\begin{tabular}{|c|c|c|c|c|}
\hline Date & $\begin{array}{c}\text { Volume } \\
\text { Dredged, } \\
\text { cu yd }\end{array}$ & $\begin{array}{c}\text { Nearshore } \\
\text { Placement } \\
\text {, cu yd }\end{array}$ & $\begin{array}{c}\text { Beach Fill, } \\
\text { cu yd }\end{array}$ & $\begin{array}{l}\text { Placement } \\
\text { Length } \\
\text { (mi) }\end{array}$ \\
\hline 1986 & 121,247 & nearshore & - & 2.6 \\
\hline 1996 & 257,649 & - & 257,649 & 2.6 \\
\hline 1997 & 130,000 & - & 130,000 & 2.6 \\
\hline 1998 & 130,000 & - & 130,000 & 2.6 \\
\hline 2001 & $2,200,000$ & - & $2,200,000$ & 1.1 \\
\hline 2002-03 & $2,000,000$ & - & $2,000,000$ & 3.6 \\
\hline 2005 & $2,800,000$ & - & $2,800,000$ & 2.6 \\
\hline
\end{tabular}

Volumetric change rates (Figure 5) for the ebb-tidal delta and adjacent beaches of St. Johns County over the last several decades indicate that the beaches have historically been depleted of sediment as the ebb-tidal delta grew at rates approaching $400 \mathrm{~K} \mathrm{cu} \mathrm{yd/yr} \mathrm{(Legault} \mathrm{et} \mathrm{al.} \mathrm{2012).} \mathrm{Following} \mathrm{the}$ dredging events of the $2000 \mathrm{~s}$, the ebb-tidal delta accretion rates decreased to $200-300 \mathrm{~K} \mathrm{cu} \mathrm{yd} / \mathrm{yr}$, indicating a change in transport from the north and south adjacent beaches (Figure 5). This balance between the volumetric change rates on the adjacent beaches and inlet system is demonstrated by the decrease in accretion for the ebb tidal delta from the 1986-1999 time period, and the commensurate decrease in erosion on the adjacent beaches in their entirety.

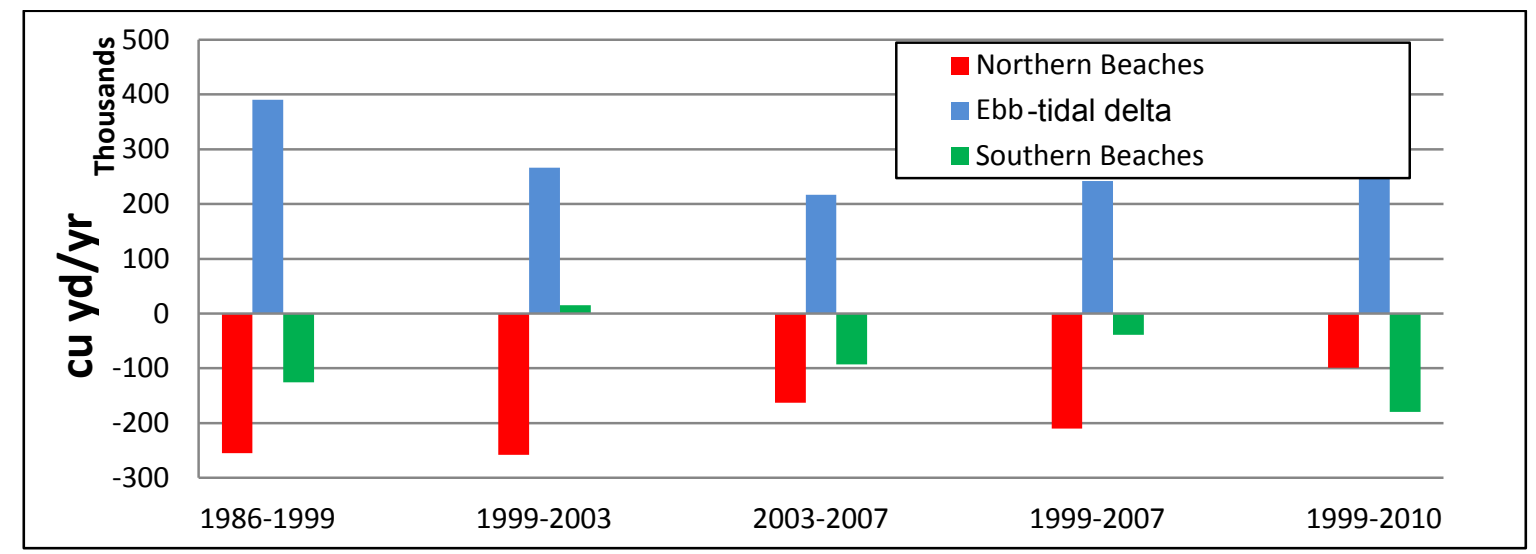

Figure 5. Volume Change for the north beaches, ebb-tidal delta, and south beaches. 


\section{Objectives}

The objective of this study is to investigate optimal dredging volumes and intervals, and to determine the beach placement volume and renourishment interval to maintain two Shore Protection Projects in St. Johns County. The principal questions to answer in this study are:

1) What is the volumetric limit (cubic yards of sediment) that can be mined at equal recurrent intervals from the ebb shoal that will not cause a significant long-term effect on the morphology and volumetric recovery of the shoal?

2) What volume of sediment and nourishment interval is required to maintain the present volume of presently authorized and planned Shore Protection Projects?

Optimization of sand mining and placement, from the inlet and on adjacent beaches, is required to identify a sustainable dredging volume and associated interval from the inlet to maintain two SPPs in St. Johns County. Nourishment volumes and placement reach alternatives are developed based on sustainable dredging volumes and intervals from the inlet ebb tidal delta and the proposed and permitted placement reaches. Ultimately, placement volumes and intervals can be optimized against sustainable dredging volumes and intervals from the ebb tidal delta to reach a long-term sediment management plan for the interactive barrier-inlet system over a 50-year planning horizon.

\section{STUDY PROCEDURE}

The Coastal Modeling System (CMS), a numerical model capable of calculating nearshore morphology change at medium-term temporal scales (years) was applied to analyze morphologic change as a function of the navigation project at St. Augustine Inlet. CMS-Flow is a finite-volume, depth-averaged model that can calculate water surface elevation, flow velocity, sediment transport (Camenen and Larson 2007), and morphology change (Sanchez et al. 2011). CMS-Wave calculates spectral wave propagation including refraction, diffraction, reflection, shoaling, and breaking, and also provides wave information for the sediment transport formulae (Figure 6). In the inline version of the Coastal Modeling System, there is shared, or coupled, forcing that is generated and subsequently passed between both CMS-Flow and CMS-Wave, including radiation stresses (with effects of wave shoaling and breaking, and roller stresses), water levels (with wave setup), current velocities, and bathymetric change. This model was chosen for this study because of its capability to reproduce potentially large impacts to the nearshore sediment dynamics at tidal inlets. Of particular interest is the capability of CMS to evaluate large-scale changes of the ebb-tidal delta morphology and inlet bypassing behavior that might interfere with gross transport of sediment to adjacent beaches.

Two CMS model grids were developed for representing St. Augustine Inlet, one for CMS-Wave and the other for CMS-Flow and sediment transport. Both grids cover the same alongshore and crossshore distances extending from the land seaward to the ocean boundary of $9 \mathrm{~km}$ and spanning the 23.5 $\mathrm{km}$ length of St. Johns County. The finest resolution of the model grid cells were set to $15 \mathrm{~m}$ in the inlet throat; $30 \mathrm{~m}$ in the main bay channels, ebb-tidal delta, and nearshore; and, a maximum cells size of $240 \mathrm{~m}$ along the offshore boundary (Figure 6). Bathymetry representing the bay, entrance channel, and ocean were assembled from several datasets including USACE entrance channel surveys, 2004 lidar (JALBTCX 2006), USACE beach profile and nearshore bathymetry surveys covering the shoreline (from USACE Jacksonville District), and offshore surveys collected by the National Ocean Service (NOAA 2010b). The historical beach profile data for St. Johns County (R-1 to R-209) were collected from the Florida Department of Environmental Protection (FDEP). Other spatially variable features or parameters included in the CMS-Flow grid are referred to in Beck and Legault (2012a) and include variable median sediment grain size D50 for sediment and Manning's n for representing bottom friction.

CMS was calibrated with measured water levels and currents from 2010, and validated with infilling volumes and morphologic change of the 2003 mining for a 1.4-year calculation. CMS calculations for several mining alternatives were used to determine if dredging excessive amounts of sediment would change the ebb-tidal delta planform area and volume to an extent where recovery to pre-dredge conditions was unlikely. Alternatives were designed to evaluate three dredging scenarios, the removal of 1.5, 3.0, and 4.0 Mill cu yd, respectively, (Figure 7) from the bathymetry surveyed in 2008. The primary features evaluated with the CMS were the sediment transport pathways and bypassing patterns, morphologic imprint, and the capacity of the mined ebb-tidal delta to maintain its bypassing potential. The evaluation of dredging alternatives better defined a dredging volume limit beyond which the system is no longer in 'equilibrium'; and, it would be expected that morphologic features including the navigation channel and bypassing pathways would be greatly compromised. In 
addition, historical accretion rates were analyzed to assess appropriate dredging volumes and intervals that would not disrupt the near-equilibrium of the pre-mining ebb delta volume over the 50 -year planning horizon.
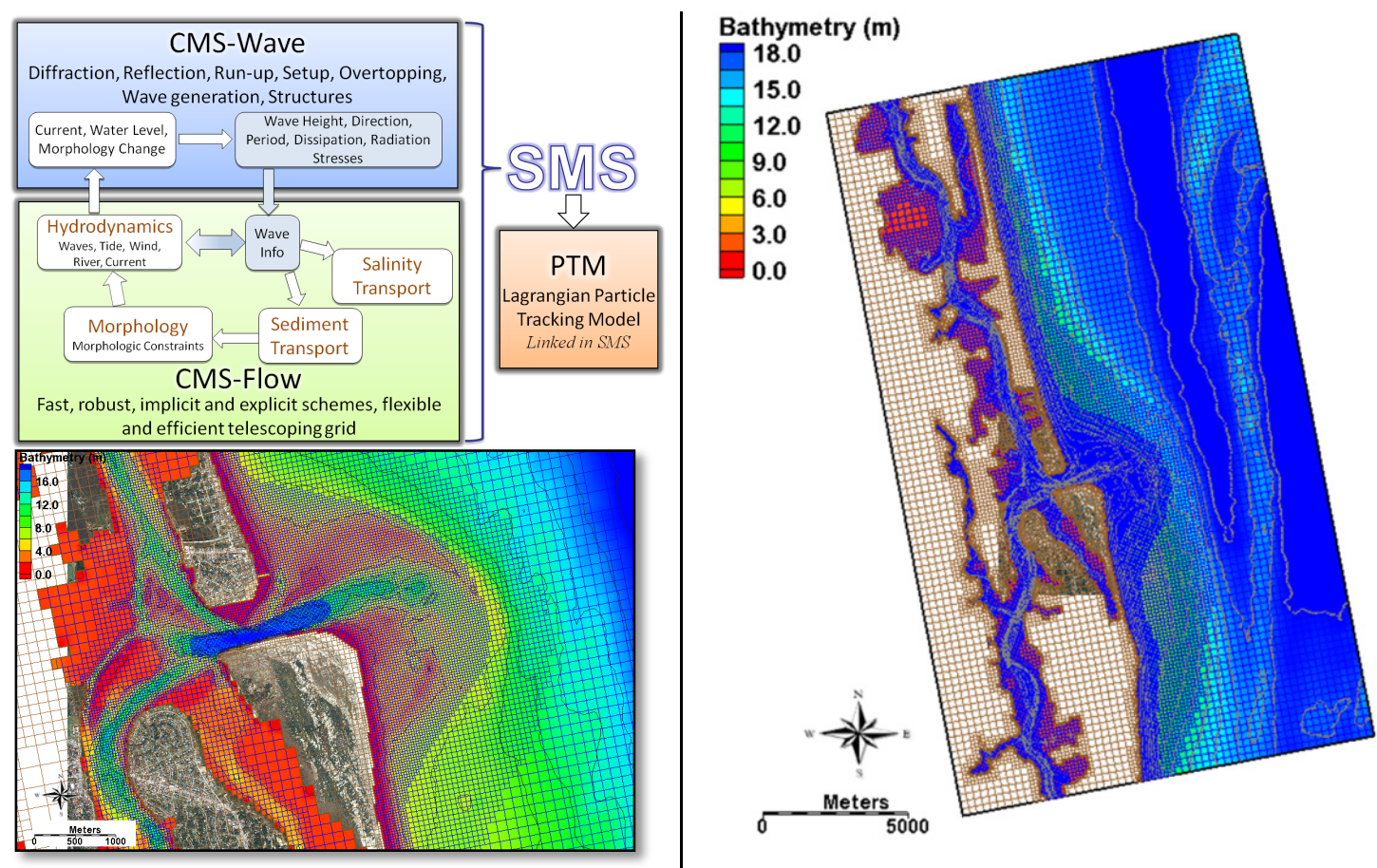

Figure 6. The CMS framework and its components (top left), the Cartesian model grid (right), and a highresolution view of the Cartesian model grid at St. Augustine Inlet (bottom left).

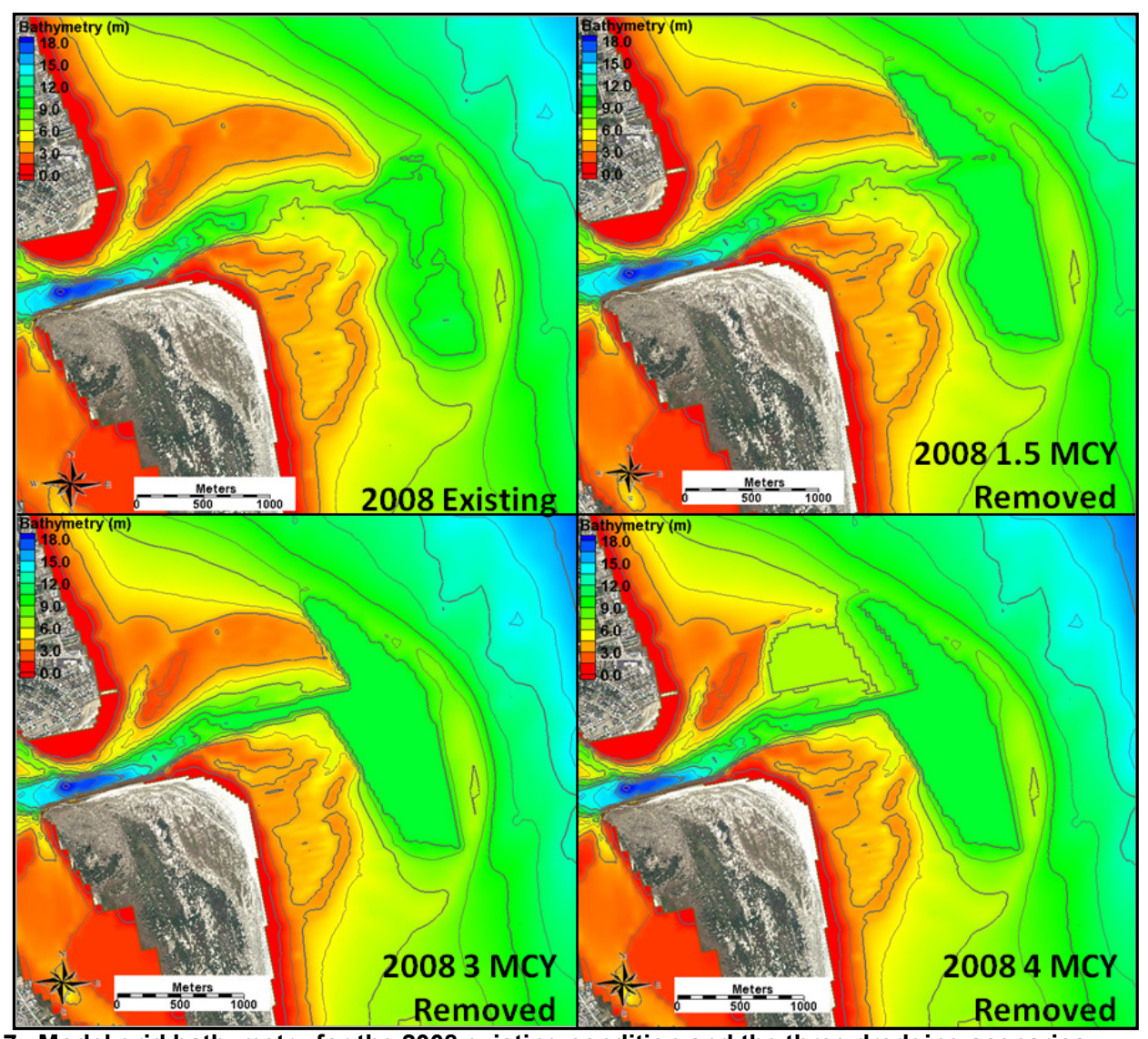

Figure 7. Model grid bathymetry for the 2008 existing condition and the three dredging scenarios. 
Using results from CMS, GenCade was applied to address sediment management questions raised previously (see: Objectives). To evaluate the accuracy of the model's prediction of sediment exchange between the beaches and inlet, GenCade was first calibrated for the time period of 1986-1999.

Calibration (GenCade User's Manual; Frey et al. 2012) is the procedure for the determination of values for adjustable coefficients that condition the model to reproduce changes in shoreline position over a specific time interval. Calibration also includes conditioning the model to reproduce known changes in inlet reservoir volumes. The information necessary to run and calibrate the model included the shoreline (defined at the MHW position) from 1986and 1999, volumes and dates of dredging (Table 2), sediment from mechanical placement (beach nourishment), the background erosion rate (Inlet Management Plan, Taylor Engineering Inc. 1996) at the boundaries, and the volumetric change of the beaches and inlet (Legault et al. 2012).

Calibration began with reproducing the average net transport rates reported in the Inlet Management Plan (Inlet Management Plan, Taylor Engineering Inc. 1996) for the St. Johns County area, which range from 200,000 to $250,000 \mathrm{cu}$ yd/year at the northern boundary of the study area, given that net transport is directed to the south. Lateral boundary conditions (LBC) for sediment transport at the north and south boundaries of the grid were set to the Moving LBC option to allow for cross-shore migration of the shoreline based on transport gradients at the boundaries. Fourteen years of WIS hindcast wave data (Waves Information Study (WIS), http://frf.usace.army.mil/wis/) from 1986 - 1999 were used for calibration, and 20 years of WIS data from 1980 - 1999 were pseudo replicated over a 50 -year period for the optimization of engineering alternatives. WIS wave data were manually modified (adjusted 5-15 degrees toward the north) from R123 to R132 to account for the refraction of waves in the vicinity of the ebb-tidal delta. Wave refraction around this area was found to drive the sediment transport to the north under all wave conditions (Beck and Legault 2012b). The result of this modification (Figure 8) more realistically reproduces documented alongshore net transport gradients and is in better agreement with measured total volume change.

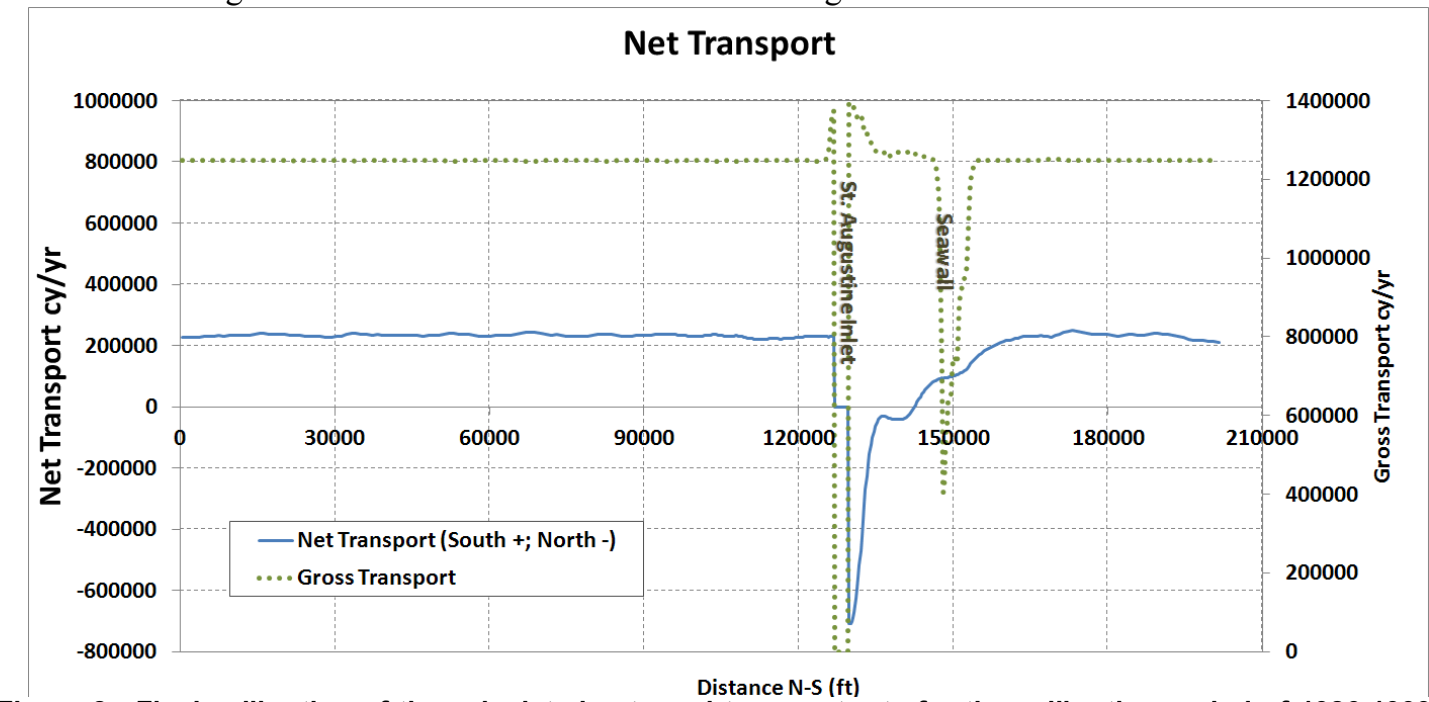

Figure 8. Final calibration of the calculated net sand transport rate for the calibration period of 1986-1999, including modified waves over the downdrift (south) side of the inlet from R123-R132.

Physical parameters that govern the behavior of St. Augustine Inlet were established and tested for sensitivity as a function of inlet bypassing location and terminal groin permeability. Because dredging occurs within the confines of the ebb-tidal delta, it was assumed that all volume change could be represented as occurring within a single morphologic feature in the Inlet Reservoir Model (see Kraus 2000 for more information on the potential reservoirs of an inlet). Total equilibrium volume was set to 40 Mill cu yd based upon values in Table 1. The bypassing, or exchange, of sediment from IRM and adjacent beaches occurred at the one cell directly adjacent to the updrift side of the ebb shoal represented in the IRM, and collectively at 26 cells directly adjacent to the down drift side of the ebb shoal ( $\sim 6,500 \mathrm{ft}$ to the end of the protruded headland along Anastasia State Park). The permeability of the terminal groins (between $0 \%$ and $100 \%$ ) were estimated based on visual inspection of sand infiltration in aerial photos, and were $80 \%$ for the north jetty (largely ineffective with no notable shoreline offset) and $30 \%$ for the south jetty (when not buried). In addition to groin permeability, a bypassing coefficient for each side of the inlet was calibrated to represent the capacity of the adjacent shoreline volume to pass sand to and accept sand from the inlet reservoir system. These bypassing 
coefficients were set to 0.5 for the north coefficient and 70 for the south coefficient. Final inlet reservoir volumes for the calibration period had a relative difference of $-36 \%$ from the measured volume.

A well-documented background erosion rate (Taylor Engineering Inc. 1994) $80 \mathrm{cu} \mathrm{yd} / \mathrm{hr}$ (or, $700 \mathrm{~K}$ cu yd per year), initially not specified for the calibration tests, was included in the final calibration of the entire model domain. The inclusion of the background erosion rate significantly improved the calibration of the model (Figure 9). The statistical relationship between the model results and measured data were as follows:

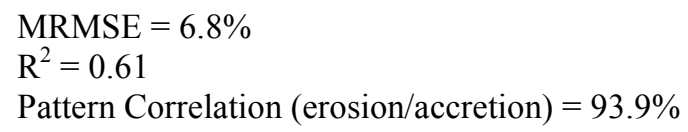

Calibration to transport rates and directions, shoreline change rates, and general geomorphic response resulted in acceptable statistics between the model results and measurements. The model was very sensitive to the IRM and to hard structures (the seawall at St. Augustine Bach). In addition, known, large-scale events, typically beach nourishment, dominated the signature of the shoreline represented in the model. Finally, as a function of the natural geomorphology of the region, the growth of the attachment location of the ebb-tidal delta and the downdrift beach can be readily seen in resulting model runs. Table 3 lists the final calibration parameters set in the model.

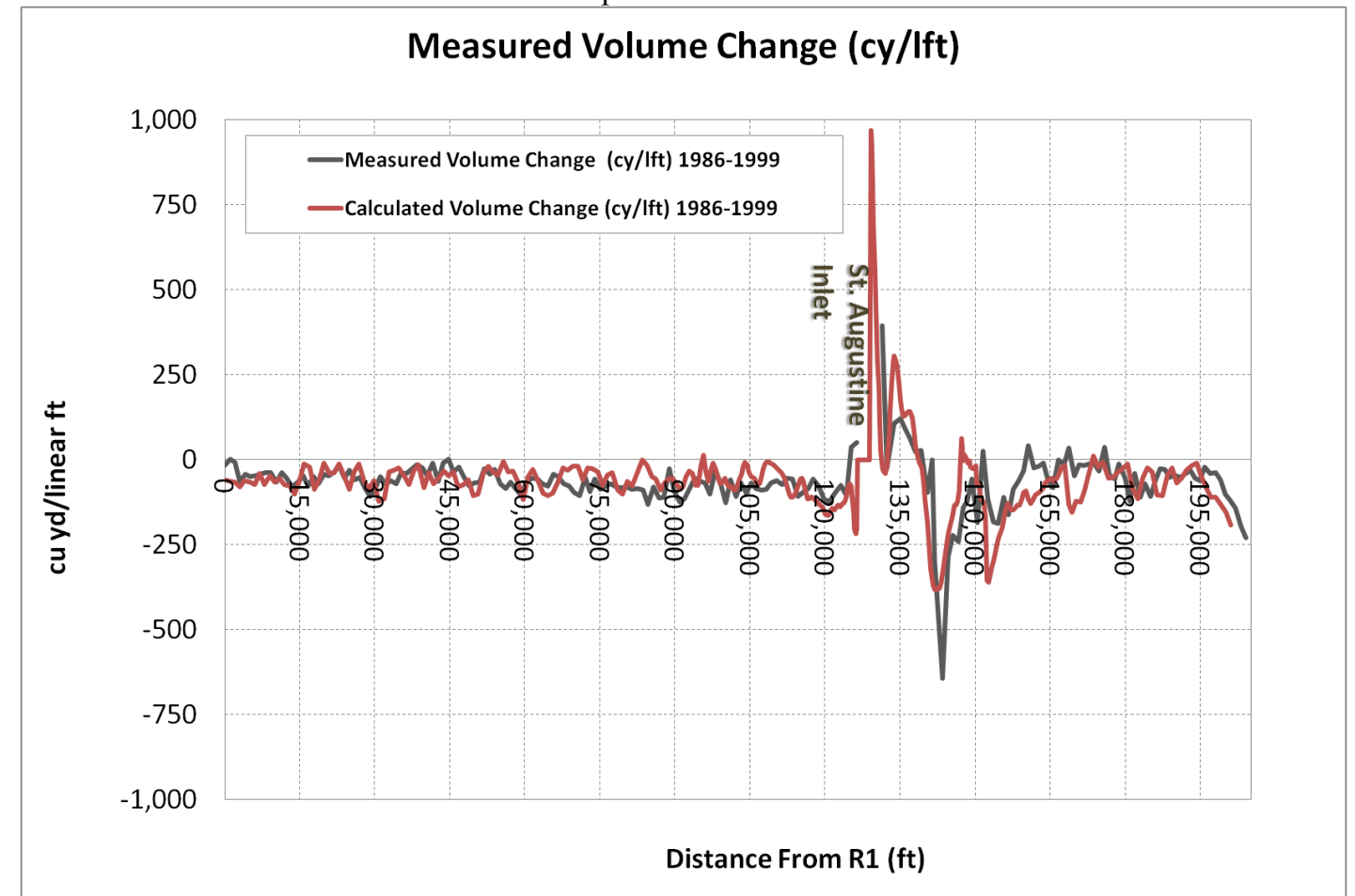

Figure 9. Measured vs. calculated profile volume change for the calibration period of 1986-1999 that includes the background erosion rate.

\begin{tabular}{|c|c|c|c|}
\hline \multicolumn{4}{|l|}{ Table 3. GenCade model feature coefficients applied for the 50-yr alternatives. } \\
\hline Feature & Value & Feature & Setting \\
\hline K1 Coefficient & 0.6 & $\begin{array}{c}\text { Background Erosion Rate (Bypassing } \\
\text { Rate) }\end{array}$ & -80 cu yd/hr \\
\hline K2 Coefficient & 0.4 & Left (north) Lateral Boundary Condition & $\begin{array}{c}\text { Moving; 0 ft per } \\
\text { simulation }\end{array}$ \\
\hline D50 (mm) & 0.2 & $\begin{array}{c}\text { Right (south) Lateral Boundary } \\
\text { Condition }\end{array}$ & $\begin{array}{c}\text { Moving; 0 ft per } \\
\text { simulation }\end{array}$ \\
\hline Berm Height (ft MSL) & 5 & $\begin{array}{c}\text { Inlet Left (north) Jetty Bypassing } \\
\text { Coefficient (JBCL) }\end{array}$ & 0.5 \\
\hline Depth of Closure (ft MSL) & 20 & Inlet Right (south) Jetty Bypassing \\
Coefficient (JBCR) & 2 \\
\hline Ismooth (averaging window) & 1 & Inlet Left (north) Jetty Porosity & 0.8 \\
\hline Time Step (hr) & 0.0625 & Inlet Right (south) Jetty Porosity & 0.3 \\
\hline
\end{tabular}




\section{RESULTS}

CMS was applied to assess whether additional excavation of the ebb-tidal delta would significantly change the entire ebb-tidal delta bathymetry, not just the borrow area excavation alone, by reducing its depth either through deflation or collapse, and/or reducing its planform such that it would result in a significant adverse impact to the coastal littoral system and adjacent beaches. The results of the alternative dredging scenarios in the CMS for a 1.4-year morphologic calculation indicated that whereas the 1.5, 2, and 3 Mill cu yd removed alternatives retained the general morphology and bypassing patterns, the 4 Mill cu yd removed alternative produced notable changes in the capacity of the inlet to bypass material (Figure 10). Certain conditions may either deflate or entirely collapse the active shoal through the disruption of the bypassing pathways. A distinct difference between the 3 and 4 Mill cu yd removed alternatives (Figure 10) were observed in the left northern lobe of the ebb-tidal delta, otherwise referred to as the updrift channel margin linear bar. For the $4 \mathrm{Mill} \mathrm{cu}$ yd removed alternative, the updrift (north) flood marginal channel has filled in and the main ebb channel has migrated rapidly to the north, reshaping the ebb-tidal delta and changing the bypassing pathways. The loss of functionality to transport sediments along the morphologic features of the inlet will force the bypassing out of equilibrium. For St. Augustine Inlet, the updrift channel margin linear bar is a crucial feature in the bypassing system as it functions as an essential feedback element to sustain the channelized ebb flow, which is a primary pathway for the observed tidally-dominated sediment transport patterns around the inlet (Beck and Legault 2012a). All future alternatives except for the 4 Mill cu yd mining alternative did not show significant alteration to neither morphologic features nor ebb-tidal delta volume over the time period simulated. These alternatives were, therefore, included for the optimization analysis within GenCade.
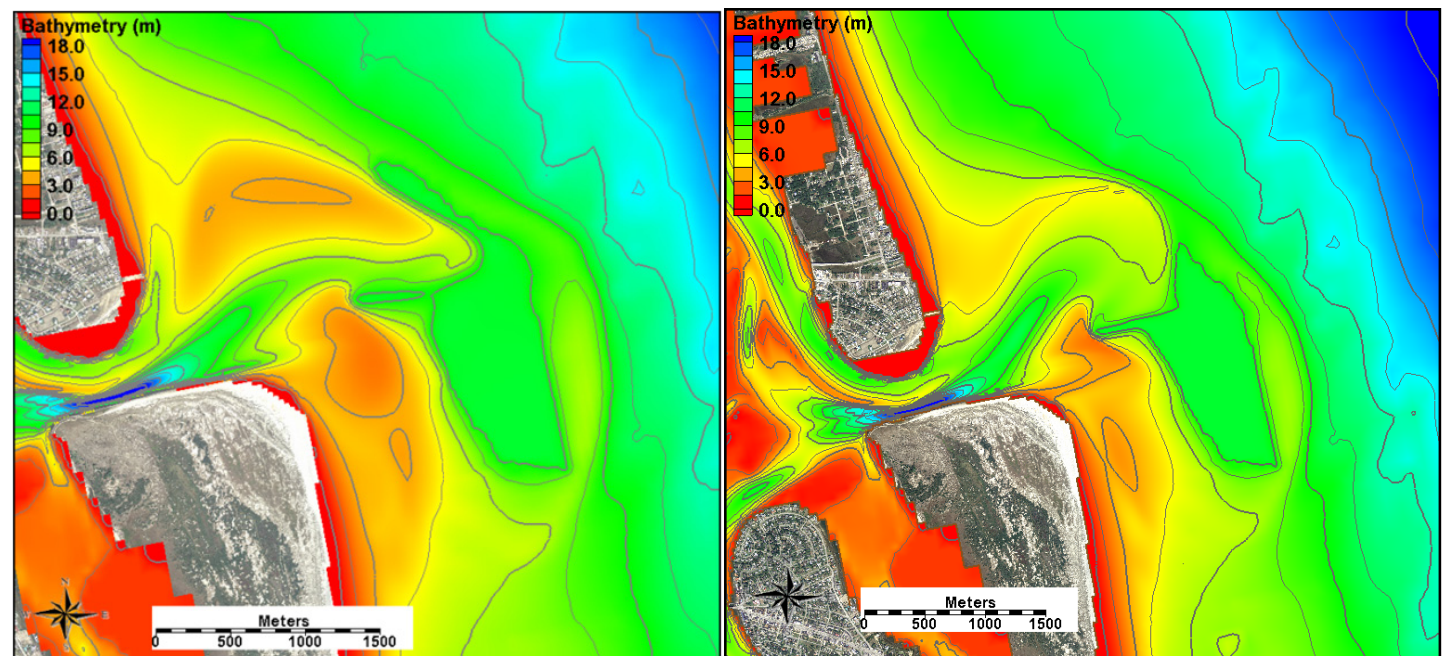

Figure 10. Calculated morphologic results for the 1.4-year simulation of the 3 and 4 Mill cu yd Removed' dredging alternatives (Beck and Legault 2012a).

Historically, infilling rates of the dredging borrow area of the ebb-tidal delta at St. Augustine Inlet has varied over time. The rate of initial infilling for the first year was only $\sim 200 \mathrm{~K} \mathrm{cu} \mathrm{yd/yr}$ when compared with the pre-dredging average of $\sim 400 \mathrm{~K}$ cu yd/yr between 1986 and 1999 (Legault et al. 2012). However, cumulatively averaged over time (Figure 11), the rate of volumetric change can be best described as a logarithmic function approaching larger rates over time. Because the rate of volumetric change is not linear over timescales of proposed successive dredging intervals (e.g. 5, 7, and 10 years), the potential volumes removed must be evaluated for this time-varying rate of change. Ebbtidal delta growth is plotted as a function of time for various dredging volumes at 5, 7 and 10 year recurrence intervals (Figure 12). Although some of these potential volumes can be removed without a significant short-term morphologic impact to the inlet, a conservative approach to selecting optimal alternatives is applied here by neglecting to evaluate alternatives that would possibly deplete the ebbtidal delta volume beyond its present volume. For this reason, a test matrix was developed (Table 4) for optimizing the dredging intensity in terms of volume removed and recurrence interval. 


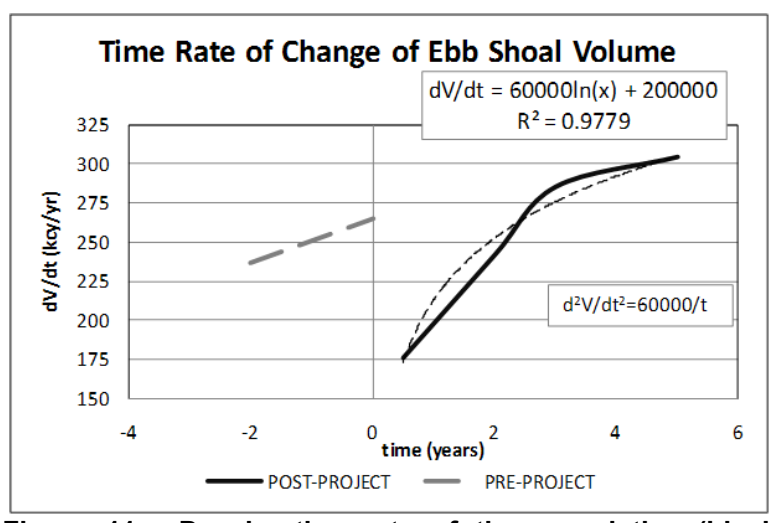

Figure 11. Deceleration rate of the cumulative (black dashed line), long-term average of the ebb-tidal delta volume change rate for each measurement period. The 2003 post dredging period and the 2005 post dredging periods are separated in dashed-gray line (2003) and black (2005).

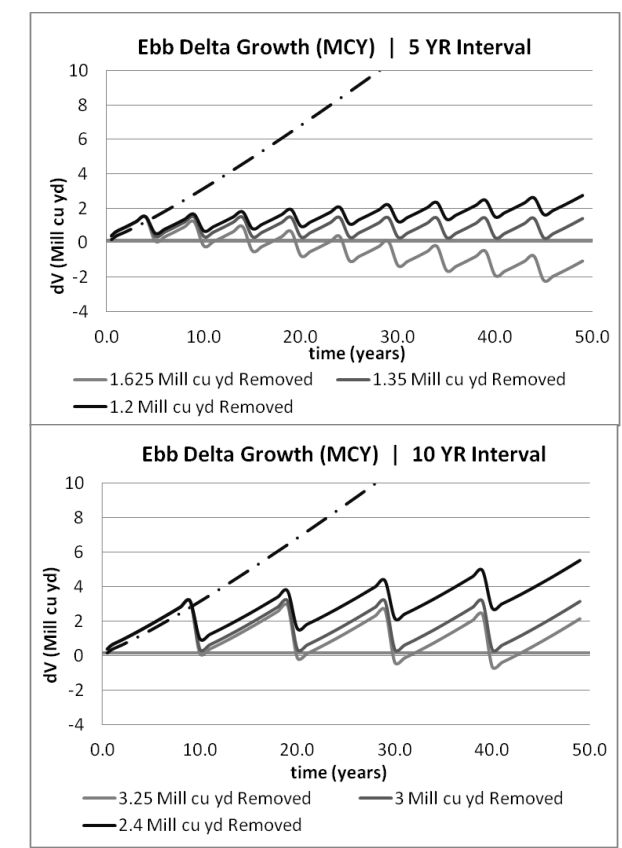

Figure 12. Time rate of change of the ebbtidal delta volume in a 5-year (left) and a 10 year (right) mining scenario.

\begin{tabular}{|c|c|c|c|c|}
\hline \multicolumn{3}{|c|}{ Table 4. Dredging intensity scenarios considering equal or accretional status of the ebb-tidal delta. } \\
\hline Scenario & $\begin{array}{c}\text { Dredged } \\
\text { Volume }\end{array}$ & $\begin{array}{c}\text { Dredging } \\
\text { Interval }\end{array}$ & $\begin{array}{c}\text { Beach Placement } \\
\text { Volume }\end{array}$ & $\begin{array}{c}\text { Beach Placement Location \& Length } \\
\text { (linear feet) }\end{array}$ \\
\hline Alt A1 & 1.0 Mill cu yd & 5 Years & 1.0 Mill cu yd & T137a - R151 (15,000 lft) \\
Alt A2 & 1.35 Mill cu yd & 5 Years & 1.35 Mill cu yd & T137a - R151 (15,000 lft) \\
Alt A3 & 2.0 Mill cu yd & 7 Years & 2.0 Mill cu yd & T137a - R151 (15,000 lft) \\
Alt A4 & 3.0 Mill cu yd & 10 Years & 3.0 Mill cu yd & T137a - R151 (15,000 lft) \\
\hline
\end{tabular}

Dredging alternatives A1 through A4 evaluate the changes in the inlet reservoir, namely the ebbtidal delta volume change, and the adjacent beach volume change for a single placement location at the St. Augustine Beach SPP. Time series of volume change for the ebb-tidal delta for the four dredging alternatives are plotted in Figure 13. Applying historical channel infilling rates, the majority of the scenario alternatives resulted in a modest change in the total volume of the ebb-tidal delta for a 50-year model run. Given that the dredging intensity within the text matrix would not greatly affect the ebbtidal delta volume, a set of alternatives were next developed to analyze the shoreline response to varying beach fill placement volumes, lengths, and locations. Three placement reaches were tested, the location of which included two authorized templates for beach placement at the St. Augustine Beach SPP, and the new design template for Vilano Beach. Figure 14 outlines the reaches for each placement by R-Monument profile locations. In Table 5, optimized beach fill placement scenarios are described, including the fill volume in cubic yard/linear food (cu yd/lft) and the linear length of beach. 


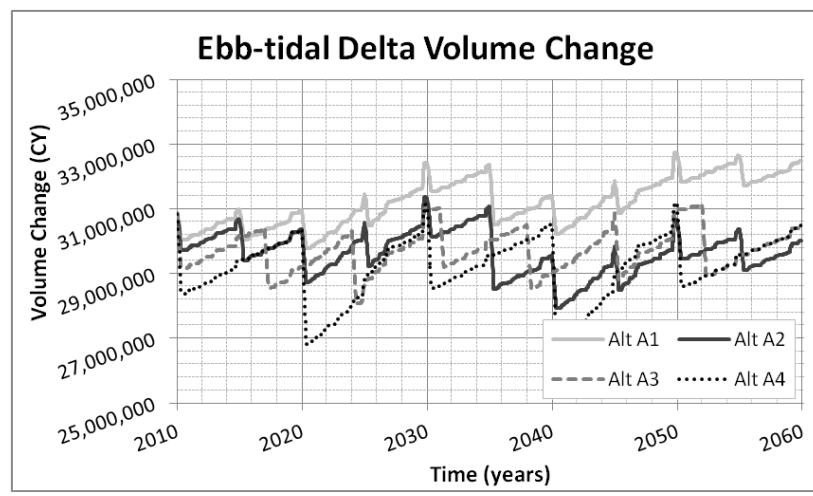

Figure 13. Time-series plot of the ebb-tidal delta volume change for Alts A1-A4.

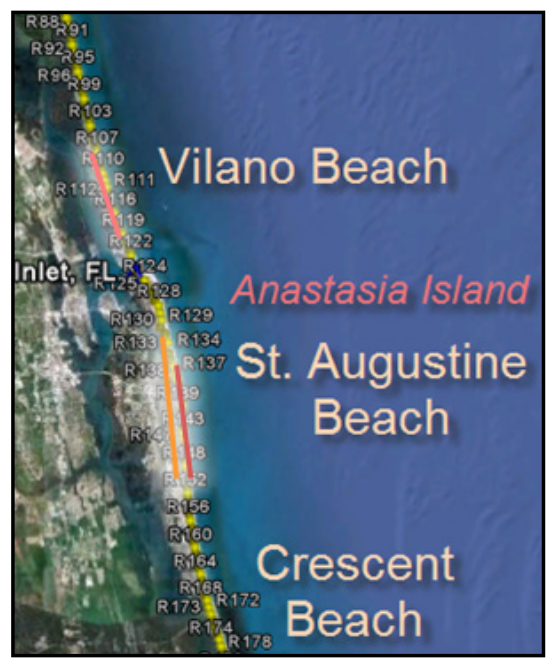

Figure 14. Beach placement reaches and $\mathrm{R}$-monument profiles located along Vilano (R109-R120) and St. Augustine (T132-R151; T137a-R151) Beaches.

\begin{tabular}{|c|c|c|c|c|c|}
\hline Scenario & Dredged Volume & $\begin{array}{l}\text { Dredging } \\
\text { Interval }\end{array}$ & \multicolumn{2}{|c|}{ Beach Placement Volume } & $\begin{array}{l}\text { Beach Placement Location } \\
\text { \& Length (linear feet) }\end{array}$ \\
\hline Alt B1 & 1.35 Mill cu yd & 5 Years & 1.35 Mill cu yd & $70 \mathrm{cu} \mathrm{yd/ft}$ & T132 - R151 (20,000 lft) \\
\hline Alt B2 & $\begin{array}{l}\text { 1.65 Mill cu yd (Includes } \\
\text { Vilano Shoal) }\end{array}$ & 5 Years & 1.65 Mill cu yd & $\begin{array}{l}40 \mathrm{cu} \mathrm{yd} / / \mathrm{ft} \\
80 \mathrm{cu} \mathrm{yd} / / \mathrm{ft}\end{array}$ & $\begin{array}{l}\text { R109 - R120 (11,000 lft) } \\
\text { T137a - R151 (15,000 lft) }\end{array}$ \\
\hline Alt C1 & 3.0 Mill cu yd & 10 Years & 3.0 Mill cu yd & $\begin{array}{l}50 \mathrm{cu} \mathrm{yd} / / \mathrm{ft} \\
125 \mathrm{cu} \mathrm{yd} / \mathrm{ft}\end{array}$ & $\begin{array}{l}\text { R109 - R120 (11,000 lft) } \\
\text { T132 - R151 (20,000 lft) }\end{array}$ \\
\hline Alt C2 & 3.0 Mill cu yd & 10 Years & 3.0 Mill cu yd & $\begin{array}{l}100 \mathrm{cu} y d / / \mathrm{ft} \\
125 \mathrm{cu} y d / / \mathrm{ft}\end{array}$ & $\begin{array}{l}\text { R109-R120 (11,000 lft) } \\
\text { T137a-R151 (15,000 lft) }\end{array}$ \\
\hline
\end{tabular}

Percent volume change for the three reaches and the ebb-tidal delta are shown in Figure 15 for all modeled alternatives. Anastasia State Park is included in the figure because it is directly connected to the volume change in the inlet reservoir model, is naturally accreting, and, therefore, is an important contrast to the other projects. For all A Alternatives, there is no positive benefit to any of the adjacent beaches except for Anastasia State Park. The greatest reduction in beach volume loss for the St. Augustine Beach SPP was determined to be at 7 year intervals for A3, although this was not significant enough to distinguish between 7 and 10 years intervals. Volume change of the ebb-tidal delta did indicate a positive volumetric response when the inlet is dredged over longer time periods (i.e. 10 years).

For the varying beach fill alternatives (Figure 15, right), Alternatives B1 and B2 compared similar dredging intensity; however, alternative B2 included the beach project at Vilano Beach. Alternative B1 lost approximately 1 Mill cu yd over the 50 years, with B2 resulting in $\sim 60 \%$ less erosion than B1. Alternatives $\mathrm{C} 1$ and $\mathrm{C} 2$ had a net volume gain for Vilano beach. Alternative $\mathrm{C} 1$ calculated the least volume lost to the St. Augustine Beach SPP for the 10-year interval, and resulted in no volume change for Vilano beach indicating that a minimum of $50 \mathrm{cu} \mathrm{yd} / \mathrm{lft}$ of beach fill every 10 years was sufficient to maintain this future project. The very high volume retention within Anastasia State Park is likely the result of the wider beach fill in $\mathrm{C} 1$ for St. Augustine Beach SPP than in C2, and may also result from sediment transport to the north due to the reversal that is not bypassed into the inlet due to a lack of inlet processes represented in the model. Overall, Alternative $\mathrm{C} 1$ resulted in the best performance of all of the projects, including the ebb-delta mining, and resulted in an optimal regional inlet and beach management plan for St. Johns County. However, as indicated in the results of Alt A3, vastly larger quantities of material placed along St. Augustine Beach SPP, and across the longer permitted length of placement $(20,000 \mathrm{lft})$ resulted in the best performance of the existing projects. 


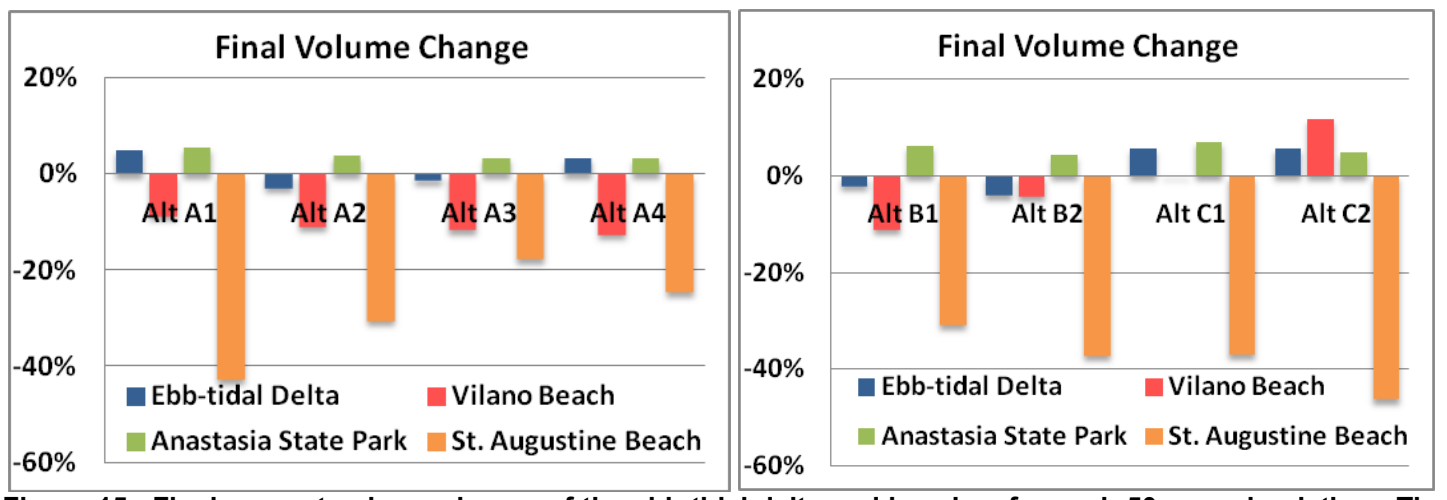

Figure 15. Final percent volume change of the ebb-tidal delta and beaches for each 50-year simulation. The beach volume change percent is a relative difference from the total profile volume (from R-Monument to -20 $\mathrm{ft}$ MLW) which has an arbitrary start elevation at the dune line per profile.

\section{DISCUSSION}

Two models were applied to a regional sediment management study on the interactions between a tidal inlet and the adjacent beaches of St. Johns County, Florida. The goal of their use was to optimize the dredging and beach placement projects that occur at various time scales over a 50-year planning horizon. The Coastal Modeling System was applied to analyze the morphological impact on sediment dynamics at St. Augustine Inlet over short-term time scales. Results of the CMS modeling point to a strong sensitivity to the dredging area over which material was removed where significant planform area change significantly modified the ebb-tidal delta morphology. The 4 Mill cu yd removed alternative removed sediment over a significant area of the updrift channel margin linear shoal, thus offsetting the equilibrium of sediment bypassing and ultimately the morphology of the inlet's ebb-tidal delta (Beck and Legault 2012a). The results of this analysis on sustainable dredging volumes, combined with historical infilling rates, provided the constraints with which to develop dredging and beach fill scenarios for the region.

GenCade was applied to this study as a planning tool to evaluate the trajectory of the sediment sources and sinks over time. An initial set of alternatives (A) evaluated the response of the inlet volume and a single Shore Protection Project by varying the dredging intensity. Results of these test informed the development of B and $\mathrm{C}$ Alternatives for evaluating beach fill volumes and reaches for the two Shore Protection Projects. All alternatives were found to have a negative volume adjustment, or shoreline erosion, for the St. Augustine Beach SPP over the 50-year simulation. This beach is characteristic of an eroding headland with an extensive sea wall that further complicates the beach dynamics. The shoreline and profile volume of this beach cannot be maintained with the St. Augustine ebb-tidal delta source alone. Managers may consider other sand resources, and temporally varying their use of the ebb-tidal delta to mitigate excessive erosion (Beck and Legault 2012b).

The second beach fill project, at the proposed Vilano Beach location, was calculated to maintain and even grow with $\sim 50 \mathrm{cu}$ yd/linear-foot beach fill volumes at 10 -year intervals. This is found in conjunction with concurrent beach fill at St. Augustine Beach, which is considered to have a larger impact on the inlet dynamics and, therefore, on the updrift adjacent beaches. Additionally, Vilano Shoal was found to be a vital source for Vilano beach in shorter dredging intervals. This shoal is directly connected to Vilano Beach, and yet is also a part of the inlet reservoir; and, therefore, must be considered on the time scales of that reservoir's infilling rate. However, if applicable, lengthening the Vilano Shoal dredging interval and coordinating it with the ebb-tidal delta mining for the St. Augustine Beach SPP will provide more than enough sand to maintain Vilano Beach at $50 \mathrm{cu}$ yd/lft (Beck and Legault 2012b). In addition, the calculated volume growth at Anastasia State Park represents sediment volumes that might otherwise make it to the inlet shoals. Regardless of the limitations on represented inlet processes in the model, inferences on the significant of this volume to the inlet reservoirs may still be included in the analysis of the results.

The results of the optimization alternatives modeled in GenCade were examined in this study as discrete sediment fluxes that make up a complete budget. This tool provides planner and managers the opportunity to coordinate dredging intervals simultaneously with varying beach fills, and to reevaluate, or optimize, with newly informed forcing and data. This method is a benefit to managers over analytical budgeting periods because real world forcing including storms and time-varying sediment dynamics can be applied to the projected calculations. A more prudent benefit lies in determining 
optimal mobilization periods and coordinating regional efforts to save in mobilization and demobilization costs of equipment for dredging and beach fill placement.

\section{CONCLUSIONS}

An analysis of the Coastal Modeling System model results determined that dredging scenarios under 4 Mill cu yd removed did not significantly modify the ebb-tidal delta through the 1) elevation and planform extent, 2) sediment transport patterns, or 3) volume flux provided to the adjacent beaches. The CMS modeling results on sustainable dredging volumes, combined with historical infilling rates, provided the constraints with which to develop dredging and beach fill scenarios for GenCade. These restraints were transferred to the Inlet Reservoir Model within GenCade, and applied via modification of sediment bypassing around the inlet.

GenCade was applied to evaluate sediment management alternatives for dredging intervals of 5, 7 and 10 years, and varying beach fill volumes and placement lengths. Results indicate that imposing a 10 -year dredging interval to the navigation project and ebb delta with the maximum dredging quantity of 3 million cubic yards will yield the best performance of the regional projects of St. Johns County. Smaller intervals and volumes of sand removed resulted in a long-term decrease in sediment retention and an overall reduction in benefits to the regional projects. Results clearly indicated that there is not a sustainable dredging amount and interval for St. Augustine Inlet that will meet the beach fill needs of the St. Augustine Beach SPP alone, and that at least another 1 Mill cu yd/yr would be needed. These results will facilitate well-defined planning decisions.

The benefits of coordinating and modifying dredging volumes and intervals can be explored in GenCade simultaneously with varying beach fill volumes and intervals to calculate how sediment sources and sinks evolve over time for future sediment budgets. These technical improvements in modeling capabilities are critical as sponsors, customers, and regulatory agencies expect an ever increasing level of modeling detail and ever-better accuracy in time-varying predictions for beach and coastal navigation systems. The greatest benefit of this methodology to managers and planners is in determining optimal dredging periods and coordinating regional efforts to save in mobilization and demobilization costs for dredging and beach fill placement.

\section{ACKNOWLEDGMENTS}

The authors would like to thank two anonymous reviewers for making valuable contributions to this work. This project was partially funded by the National Regional Sediment Management and Coastal Inlets Research Programs of the U.S. Army Corps of Engineers.

\section{REFERENCES}

Beck, T.M., and K.R. Legault. 2012a. St. Augustine Inlet, Florida: Application of the Coastal Modeling System, Report 2. Technical Report ERDC-TR-12-4: Report 2, U.S. Army Research and Development Center, Coastal and Hydraulics Laboratory, Vicksburg, Mississippi.

Beck, T.M., and K.R. Legault 2012b. Optimization of Ebb Shoal Mining and Beach Nourishment at St. Johns County, St. Augustine Inlet, Florida. Technical Report ERDC/CHL-TR-12-14: Report 3, US Army Engineer Research and Development Center, Coastal and Hydraulics Laboratory, Vicksburg, Mississippi.

Camenen, B., and M. Larson. 2007. A Unified Sediment Transport Formulation for Coastal Inlet Application. Contract Report ERDC/CHL-CR-07-1, US Army Engineer Research and Development Center, Coastal and Hydraulics Laboratory, Vicksburg, MS.

Demirbilek, Z., and J.D. Rosati. 2011. Verification and validation of the Coastal Modeling System: Executive Summary. Technical Report ERDC/CHL-TR-11-XX. U.S. Army Engineer Research and Development Center, Coastal and Hydraulics Laboratory, Vicksburg, MS.

Frey, A.E., K.J. Connell, H. Hanson, M. Larson, R.C. Thomas, S. Munger, and A. Zundel. 2012. GenCade Version 1 Model Theory and User's Guide. Technical Report ERDC/CHL TR-12-XX (in print), U.S. Army Engineer Research and Development Center, Vicksburg, MS.

Hanson, H., K.J. Connell, M. Larson, N.C. Kraus, T.M. Beck, and A.E. Frey. 2011. Coastal Evolution Modeling at Multiple Scales in Regional Sediment Management Applications. Proceedings of Coastal Sediments '11. Vol. 3, pp. 1920-1932.

JALBTCX. 2006. 2004 US Army Corps of Engineers (USACE) Topo/Bathy Lidar: Alabama, Florida, Mississippi and North Carolina. Joint Airborne LiDAR Bathymetry Technical Center of Expertise (JALBTCX). NOAA's Ocean Service, Coastal Services Center (CSC): $<$ http://www.csc.noaa.gov/ldart>; Charleston, SC. 
Kraus, N.C. 2000. Reservoir Model of Ebb-tidal Shoal Evolution and Sand Bypassing. J. Waterway, Port, Coastal, and Ocean Eng., 126(6), 305-313.

Legault K.R., J.D. Rosati, J. Engle, and T.M. Beck. 2012. St. Johns County, St. Augustine Inlet, FL Report 1: Historical Analysis and Sediment Budget. Technical Report ERDC-TR-12-4: Report 1, U.S. Army Research and Development Center, Coastal and Hydraulics Laboratory, Vicksburg, MS.

NOAA 2010a. "Tides and currents," National Oceanographic and Atmospheric Administration, http://tidesandcurrents.noaa.gov/, accessed 17 April 2010.

NOAA 2010b. "NOAA Bathymetry". National Oceanographic and Atmospheric Administration. https://www.ngdc.noaa.gov/mgg/bathymetry/relief.html, accessed 3 March 2010.

Sanchez, A., W. Wu, T.M. Beck, H. Li, J.D. Rosati., Z. Demirbilek, and M. Brown. 2011. "Verification and Validation of the Coastal Modeling System, Report 4: Sediment Transport and Morphology Change," ERDC/CHL-TR-11-10, US Army Engineer Research and Development Center, Coastal and Hydraulics Laboratory, Vicksburg, Mississippi.

Taylor Engineering, Inc. 1994. Phase I - Literature Search. St. Augustine Inlet Management Plan, St. Johns County, Florida.

Taylor Engineering, Inc. 1996. Inlet Baseline Conditions Physical and Environmental Characteristics. St. Augustine Inlet Management Plan - Part 2, St. Johns County, Florida.

USACE-SAJ. 2010. Dredging Information System (DIS) Database, maintained by the U.S. Army Corps Engineer Jacksonville District, Jacksonville, Florida.

Walton, T. L., and W. D. Adams. 1976. Capacity of inlet outer bars to store sand. Proceedings $15^{\text {th }}$ Coastal Engineering Conference, ASCE, 1,919-1,937.

WIS: Waves Information Study. 2010. Developed by the US. Army Engineer Research and Development Center, Coastal and Hydraulics Laboratory, Vicksburg, MS. http://frf.usace.army.mil/wis/. 